\title{
History and Seismology in the Ring of Fire Punctuating the Indonesian Past
}

\author{
Anthony Reid
}

Terrifying spasms of the planet like the one that struck northern Honshu in March 2011, or Aceh and much of the Indian Ocean littoral on Boxing Day 2004, force us to reflect on what our discipline is about. The longer the time-depth considered, the more human history can be seen to be dependent on the beneficence of the planet we inhabit. In our preoccupation with the rise, fall, successes and follies of states, especially of our own states, historians have often missed the larger vocation of seeking to understand the planet itself. Here Peter Boomgaard blazed a crucial trail, showing what appropriately equipped historians can do to write the history of the Southeast Asian environment as a crucial part of that of the planet. ${ }^{1}$ Yet this too risks becoming a marginal sub-discipline. The great majority of historians of Southeast Asia focus on the nineteenth and twentieth centuries, and have little contact with those we call pre-historians, let alone seismologists, geologists, life scientists and climatologists.

\section{Past Neglect}

Since 2004 Sumatra has come to be understood as one of the most active and dangerous tectonic subduction zones in the world, with the most dramatically evident periodicity of mega-events (Perkins 2008). But the historians and others who wrote about Sumatra in the late nineteenth and twentieth centuries did little to prepare their readers for violent earthquakes, tsunamis, volcanic eruptions and climatic aberrations. Authors such as C. Snouck Hurgronje, E.S. de Klerck, E.B. Kielstra, John Bastin, Denys Lombard, James Gould, Mohammad Said, Ibrahim Alfian, Christine Dobbin, J. Kathirithamby-Wells, Freek Colombijn and myself virtually ignored natural events, though we have done a little better since $2004 .^{2}$

1 Firstly by leading the KITLV project on Ecology, Demography and Economy in Nusantara (EDEN) for 15 years, and finally in his path-breaking Southeast Asia: An Environmental History (Santa Barbara: ABC Clio, 2007).

2 To be fair, Freek Colombijn (1994:43) had one sentence noting that Padang was virtually destroyed by the 1797 earthquake. Since 2004 we have all done better, including Colombijn in

(C) ANTHONY REID, 2015 | DOI 10.1163/9789004288058_006

This is an open access chapter distributed under the terms of the Creative Commons Attribution-

Noncommercial 3.0 Unported (CC-BY-NC 3.0) License. 
The disasters which have succeeded one another between the AcehNias tsunami of December 2004 and the South Pagai (Mentawai) tsunami of October 2010 (Table 5.1) appeared unprecedentedly ferocious to Indonesians living today, but were 'business as usual for the earth' (McCaffrey 2009:363). We now know that such ruptures in the earth's crust occur with necessary regularity, and that the bigger events every few centuries have enormous impacts not only on Indonesia but on the planet as a whole. Our politically-focussed histories look woefully inadequate to explain this pattern.

The regularity of disasters on the subduction zones was reported first for California and Japan, while Sumatra was little noticed even by geologists until a seminal article by geophysicists Newcomb and McCann (1987) assembled the evidence pointing to its dangers in 1987 . The scientists use the data of historians when they can, though in Southeast Asia we have not been particularly helpful to them. A comprehensive record began to be available for the whole planet only once the seismograph was invented around 19oo, and long after that descriptions of the effects of seismic movements on human

TABLE 5.1 Major seismic disasters in Indonesia since $2004^{3}$

\begin{tabular}{llll}
\hline Date & Magnitude & Place & Direct Fatalities \\
\hline 2004, 26-12 & $9.2 \mathrm{M}+$ tsunami & Aceh-Nias & 167,800 \\
2005, 28-3 & $8.6 \mathrm{M}+$ tsunami & Nias & 1,313 \\
2006, 26-5 & $6.3 \mathrm{M}$ & Yogyakarta & 5,749 \\
2006, 17-7 & $7.6 \mathrm{M}+$ tsunami & Pangandaran, W. Java & 802 \\
2007, 12-9 & $8.4 \mathrm{M}$ & Mentawai, Padang, & $25^{+}$ \\
2009, 30-9 & $7.6 \mathrm{M}$ & Padang & 1,117 \\
2010, 25-10 & $7.7 \mathrm{M}+$ tsunami & Mentawai & 400 \\
2010, 26-10 & V4 eruption & Merapi, Java & 324 \\
2012, 11-4 & 8.6 earthquake & Aceh & 5 \\
2013, 15-9 & V2 eruption & Sinabung, N. Sumatra & 17 \\
2014, 13-2 & V2 eruption & Kelut, E. Java & 7 \\
& & &
\end{tabular}

several articles, and Jeffrey Hadler (2008: ch. 6). My edited Verandah of Violence: the Background to the Aceh Problem (Singapore University Press: 2006) was named partly in recognition of Aceh's exposure to tectonic violence.

3 Earthquakes are rated by magnitude (M), volcanic eruptions by Volcanic Explosivity Index (V) on a scale from 1 to a maximum 7 , following the Smithsonian Institute Global Volcanism Program. 
societies remained underreported in Indonesia. Before 1900 our understanding is dependent firstly on the written records of observers, and increasingly on scientific investigation of the traces left by volcanic eruptions, earthquakes and tsunamis on the ground. The ring of fire around the Pacific where the periodic pattern should be clearest is for the most part deficient in historical records before 1600 , perhaps in part because of the pattern of periodic disasters. Only Japan has records back into the first millennium CE. These have preserved a pattern of earthquakes with attendant tsunamis in the Nankai subduction zone off Shikoku and southern Honshu as far back as 684, with the biggest ones in 1293 (Kamakura - over 20,000 estimated killed), 1703 (Genroku, over 100,00o perhaps killed, est. 8.o M), in 1605 (est. 7.9 M), 1707 $(8.4 \mathrm{M}), 1854(8.6 \mathrm{M})$ and $1946(8.4 \mathrm{M})$. Another huge one is therefore anticipated in that region anytime, although it was not anticipated further north in Tohuku.

Our lack of knowledge of Indonesia's tectonic past, in contrast not only with Japan but with other less populated or exposed places around the ring of fire, is strikingly borne out in the most influential data sets now available to the scholarly community. The us National Geophysical Data Center records only 26 tsunamis known in Indonesia before 1800, of which 20 were in the areas of immediate concern to the lucrative voc spice monopoly in Maluku in the seventeenth and eighteenth centuries. Four large ones were reported at the European pepper-posts of Padang and Bengkulu in Sumatra, but none in Java where the endangered south coast was then of no interest to the Dutch. By contrast 29 have been recorded in the 22 years since 1990, including 9 massive ones killing over 100 people, two of them in Java. ${ }^{4}$ Similarly for volcanic eruptions, the Smithsonian Institute list shows that since 1982 there have been 25 eruptions in the world of a scale to cause great damage (4 or more on the Volcanic Explosivity Index, or VEI, a scale extending to 7), of which 10, or $40 \%$, have been in Southeast Asia or Papua New Guinea, 5 of them $(20 \%)$ in Indonesia. Most of the others have been in underpopulated areas of the ring of fire such as Alaska or Kamchatka. The further we go back in time, however, the less well represented Indonesia is in the record, with $16 \%$ in the nineteenth century, $3 \%$ (just one recorded) in the eighteenth, $12.5 \%$ in the seventeenth, $9.5 \%$ in the sixteenth, and nothing at all in the acknowledged record before that except a suspect memory of an eruption of Krakatau in $416 \mathrm{AD}$. By contrast hundreds of eruptions over the last few thousand years have been scientifically dated elsewhere, notably in

4 NOAA National Geophysical Data Center, register of tsunami events, http://www.ngdc.noaa .gov/hazard/hazards.shtml, accessed 6 July, 2011. 
northern sections of the Pacific Ring of Fire and in New Zealand. Almost everything remains to be done in Indonesia. ${ }^{5}$

Why has there not been more attention to the earthquakes, tsunamis and volcanic eruptions that punctuate Indonesia's history? Indonesia's relative poverty and weak scientific infrastructure is of course the major reason. But in addition, the twentieth century in which adequate reporting really began appears to have been exceptionally quiet seismologically, while it was full of violence and upheaval politically. In the nineteenth century Indonesia's massive volcanic eruptions, Tambora (1815, VEI 7) and Krakatau (1883, VEI 6), darkened and cooled the whole planet and produced years without summer in Europe, though this causation has only recently been understood (Zeilinga de Boer and Sanders 2002: ch.6, ch.7). In the twentieth there were the usual frequent eruptions, including eight which have subsequently been ranked as VEI 4 for their destructive capacity. Only Gunung Agung's 1963 eruption in Bali was rated a 5 and killed some 2000 people. Even more remarkably, no mega-ruptures were recorded on the subduction zones of Sumatra or Java causing earthquakes in excess of magnitude 8 between the 1861 one in Southwest Sumatra (later reconstructed as $8.5 \mathrm{M})$ and the massive quake $(9.2 \mathrm{M})$ and tsunami of 2004. Further east, earthquakes of 8.5 and $8 \mathrm{M}$ were reported in Maluku in 1938 and 1939, an 8 in Sumba and Sumbawa in 1977, and an 8.2 in Papua in 1996, but these were in remote and less populous areas that made little impact on urban Indonesians.

Thirdly, before twentieth century changes in urbanization and building styles, Indonesians themselves were little affected by earthquakes, and appear to have avoided settling in large numbers on the coasts of Nias, western Sumatra and southern Java which were exposed to tsunamis. The people of Nias, probably the most vulnerable to tsunamis of all complex Indonesian societies, spurned their coasts completely before sea-based Dutch infrastructure arrived in the second half of the nineteenth century. They fished only in fresh-water rivers, and built their villages on hilltops where possible (Gruber 2007). Mentawai islanders were also extremely tsunami-prone and built their villages well away from the coast (Loeb 1935:134, 161). Moreover, as

5 Smithsonian Institute Global Vulcanism Program, 'Large Holocene Eruptions', http://www .volcano.si.edu/world/largeeruptions.cfm, accessed 7 June, 2012. Peter Boomgaard's list culled from Dutch sources has 13 eruptions between 1663 and 1696, all in Maluku thanks to the concentration of Dutch interest there, except for one in Flores. More research is needed to give a VEI rating to any of these, all different from the four large ones (VEI 4 or above) listed by the Smithsonian (Boomgaard 2001b:212). 
noted by Marsden ([1811] 1966:30) in the late eighteenth century, 'the usual manner of building [in light wood, bamboo and thatch], renders them [earthquakes] but little formidable to the natives'. In the more geologically active period of the eighteenth and early nineteenth centuries European settlers did treat earthquakes as a major problem for their buildings. Marsden was one such, while Alexander Hamilton ([1727] 1930, II:61) reported of Bengkulu in the early 1700 s that 'Brick or Stone Walls in that Country cannot long continue firm, because Concussions of the Earth are so frequent by Earthquakes, that solid walls are rent by the shaking of their Foundations'.

The Malay historical and literary texts most accessible to scholars have been of little help in reconstructing the record. Ian Proudfoot's splendid Malay Concordance enables one to track the usage of terms relating to earthquakes in the hundreds of texts now accessible electronically. Gempa bumi (earthquake) in some form occurs indeed 34 times on that site, but 27 of the instances are from the Malay Bible and the remaining seven (mainly from Raniri's encyclopedic Bustan as-Salatin, written in Aceh in the 1640 sut often oblivious to local conditions), also show the wrath of God through earthquakes in the central lands of the Abrahamic tradition, not in Sumatra or Java. ${ }^{6}$ The much greater seismic mega-events of the Indonesian subduction zones appear not to have become as central to the classic Malay texts as rare events in the holy lands of the Middle East.

Only since 2004 have scholars begun looking in other corners of oral and written Indonesian literature for more clues about past seismic events. Volcanic eruptions are more frequently noted in the chronicles of Java and Bali, though as omens rather than a source of destructive change. Although seismologists have hoped the Java specialists would find confirmation in them for the megaeruptions that darkened the planet in 1257 and $535 \mathrm{CE}$, the science has so far been more useful than the chronicles. ${ }^{7}$ Oman Fathurahman recently found scribbled (in Arabic) on the front page of an old Arabic manuscript by alAnsari preserved in the religious school of Tanoh Abee near Banda Aceh the

6 http://mcp.anu.edu.au, accessed in April 2010. In addition to variations of gempa and gempa bumi, I did a search for lindu, a possibly older Javanese-derived term. This yielded 102 occurrences, all in a single Kitab Takbir (Book of Omens). Drawing on some venerable Islamic traditions as well as pre-Islamic local ones, this used earthquakes as one of the many natural phenomena to be exploited for an understanding of favourable and unfavourable times for action.

7 David Keys (200o) made speculative use of the 19th century Pustaka Raja Purwa to point to Krakatau as the source of the $535^{-6}$ planetary cooling. An interdisciplinary group recently found more convincing evidence for a mega-eruption in Lombok in 1257, though reconciling the chronicle evidence with this is a task urgently awaiting attention (Lavigne et al. 2013). 
comment that 'a second destructive earthquake' occurred on Thursday 9 Jumadil akhir $1248 \mathrm{H}$ (3 November 1832) (Fathurahman 2012). This suggests there were major Aceh earthquakes leading up to the well-documented earthquake and tsunami which destroyed many buildings in Padang and Bengkulu on 27 November 1833 .

An Acehnese scholar has collected four related manuscripts, hitherto ignored, devoted to the concept of tabir gempa, or the interpretation of earthquakes. The concept tabir is more often applied to dreams, implying that hidden meanings can also be drawn from these spasms of the earth. Two of the manuscripts were located in Banda Aceh, one in Padang and one in the National Library collection in Jakarta, but all appeared to derive from the same traumatic experience of the earthquake and tsunami which caused much damage to Padang, Bengkulu and presumably other parts of Sumatra's west coast in November 1833. Variously dated from the evening of 24 November until the $27^{\text {th}}$, this is the only major earthquake and tsunami of the late eighteenth or nineteenth century to occur in the Muslim month of Rajab (1249 $\mathrm{AH}),{ }^{8}$ and all four manuscripts stress the significance of that month. One declares 'An earthquake that occurs in the month of Rajab, should it happen at subuh (first light) then the country will suffer, should it happen at dhuha (sunrise) then the water from the sea will hit hard. ${ }^{9}$ We may at least assume that the worst impact of the 1833 tsunami hit Aceh's west coast at dawn, probably on 25 November.

Clues to earlier events in the indigenous literature are even more sparse. The Hikayat Aceh says its hero (later Sultan Iskandar Muda) 'felt the earth move like the sensation of an earthquake', making his horse also tremble as an omen of coming events - in the early 160os (Iskandar 1958:156). In Barus, north of Sibolga, several different chronicle traditions tell the story of how Barus was recognized as independent of Aceh, perhaps also in the seventeenth century. In this story Sutan or Sultan Ibrahim of Barus was killed and beheaded by soldiers of the Sultan of Aceh. When the victorious sultan kicked the head of his vanquished rival in scorn, however, he was punished by God with a terrible

8 The following month, Shaban, would surely have been stressed by any later manuscripts, since both a moderate 1836 earthquake and tsunami, and the massive one of 1861, occurred in that month (as had the 1797 quake and tsunami that destroyed much of Padang).

9 'Jika pada bulan Rajab gempa ketika Shubuh alamat isi negeri itu sakit padanya. Jika pada ketika Dhuha air laut akan keras padanya', cited in Hermansyah, 'The Acehnese Adaptation and Mitigation on Earthquake and Tsunami in the 18th Century (An Ancient Manuscript Research)', paper prepared for 3rd ICAIos Conference, Banda Aceh, May 2011, kindly made available by the author. 
disease, and 'a flood devastated the country, carried away rice and cattle, and decimated the population'. Hence the Acehnese repented, and swore that the freedom of Barus would be forever respected by Aceh (Chambert-Loir 2009:512; Drakard 1990:100,102).

\section{A Relatively Quiet 120 years}

Tectonic movements are predictable, resulting from the relentless movement of the oceanic plates 'subducting' under continental plates as they collide, often in deep trenches. In the Sumatran case, the Indian Ocean plate is advancing at about 65 millimetres a year, in the middle range of those around the world, a pressure that must be periodically released in earthquakes (Heidarzadeh et al. 2008:776). But until the current round of disasters in Sumatra and Java since 2004, neither historians nor scientists had been jolted into giving Indonesia's past record the attention it deserves. Indonesia had, it now appears, been unusually devoid of major natural disasters for 120 tears after a turbulent period in the nineteenth century which had included the eruption of Tambora in 1815. This was the biggest volcanic disaster anywhere of which history has records, assigned the maximum VEI of 7 , its ash emissions blamed for producing a year without summer in much of the northern hemisphere. ${ }^{10}$ The same century witnessed the Krakatau eruption in 1883 (VEI 6), the world's second biggest in modern times, which created a dust veil carried twice around the world, which lowered global temperatures significantly. If such an event occurred tomorrow it would ground airplanes throughout the world, and create chaos for all of us. But Krakatau occurred before the age of modern measurement and record-keeping, and before the airplane.

In the geologically calmer period between 1885 and 2000 the Indonesian population grew from about 25 million to 225 million, and its urban (predominantly coastal) population from little over a million to 129 million. The period of modern measurement of earthquakes through the seismograph (from 1900) coincided with a period of misleading geological moderation, so that modern Indonesia could be built without serious consideration of the dangers it would

10 The largest volcanic threat to homo sapiens thus far appears also to have arisen in Indonesia, in the biggest eruption of them all 74,000 years ago which created Lake Toba in Sumatra. Peter Boomgaard (2007b:31) points out that this darkened the planet for six years and reduced mankind to a few thousand - 'the last almost successful attempt by "nature" to rid itself of this peculiar brand of primate'. 
eventually have to face. Since 1870 the importance of colonial ports as hubs for each province has pushed the population to cluster dangerously on this narrow plain. In a pre-2004 article I estimated the population in 1830 of the coastal plain of what is now the Province of West Sumatra had been only one tenth that of the uplands of the same province. In the Batak areas further north (present North Sumatra Province), the contrast was even greater, with about 40 times the population in the highlands as along the western coast (Reid 1998a:61-89).

In the interval between Padang's earthquakes of 1833 and 2009, the population of the West Sumatran littoral had soared from 80,00o to over two million, and for the first time surpassed the population of its safer and healthier highland hinterland. Moreover, a high proportion now lives in sub-standard but 'modern' brick and concrete dwellings highly subject to earthquake damage, whereas in past events only the handful of Europeans were affected by the collapse of such buildings. Hence the earthquake of September 2009 centred off the coast south of Padang caused a death toll of over 1000 with 135,00o homes destroyed and 1.25 million people affected, although only registered as magnitude 7.6. The much bigger shocks of 1833 and 1861, by contrast, had caused at most a handful of deaths. In Java, similarly, the exposed southern coast was almost unpopulated until the nineteenth century, but the Dutch foundation of a major base at Cilacap in 1840, and the subsequent location of an oil refinery there, have seen the population of the southern littoral grow to about two million today.

The relatively low number of casualties from Indonesia's natural disasters in the twentieth century, and the very high numbers of casualties of political conflict, mostly state-sponsored, make it unsurprising that historians should have focused on the political. Table 5.2 shows that the deaths directly attributed to political conflict in the twentieth century outnumbered those caused by geological spasms by 30 to 1 . The reversal has been dramatic since 2000, chiefly because of the extraordinary death toll of the 2004 tsunami. Natural disasters outnumbered conflict deaths 17 to 1 in the first decade of the present century. Steven Pinker has recently shown that violent deaths from human conflict have in fact declined dramatically in most places as a proportion of total deaths (Pinker 2011), even if the Indonesian figures look high in the midtwentieth century as the world-system readjusted from empires to nationstates. Since 1980 Asia has joined the global downward trend for violent conflict deaths, which looks like being permanent. Natural disasters on the other hand have already caused more deaths in Indonesia in the first decade of the twenty-first than the whole of the twentieth century, and will certainly cause many more. 
TABLE 5.2 Deaths from natural disasters and human conflict in Indonesia

\begin{tabular}{|c|c|c|c|c|c|}
\hline & $\begin{array}{l}\text { Earthquake } \\
\text { deaths }^{11}\end{array}$ & $\begin{array}{l}\text { Tsunami } \\
\text { deaths }\end{array}$ & $\begin{array}{l}\text { Volcano direct } \\
\text { deaths }\end{array}$ & $\begin{array}{l}\text { Total natural } \\
\text { disasters }\end{array}$ & $\begin{array}{l}\text { Approx. } \\
\text { direct } \\
\text { Conflict } \\
\text { deaths }\end{array}$ \\
\hline $1900-09$ & & 400 & 76 & 476 & 21,000 \\
\hline $1910-19$ & 15,020 & & 5,100 & 20,120 & 2,500 \\
\hline $1920-29$ & 777 & 128 & 263 & 1,065 & $45^{\circ}$ \\
\hline $1930-39$ & 23 & & 1,379 & 1,402 & $5^{\circ}$ \\
\hline $1940-49$ & 213 & & 117 & 330 & 363,000 \\
\hline $195^{0-59}$ & 8 & & 71 & 79 & $40,000^{12}$ \\
\hline $1960-69$ & 236 & 264 & 1,766 & 2,077 & 500,000 \\
\hline $1970-79$ & 1,410 & 175 & 727 & 2,235 & $65, \mathrm{ooo}^{13}$ \\
\hline $1980-89$ & 880 & 11 & 268 & 1,145 & 5,000 \\
\hline 1990-99 & 3,040 & 223 & 118 & 3,269 & 10,200 \\
\hline Total C2oth & 21,607 & 1,201 & 9,665 & 32,473 & $1,028,000$ \\
\hline 2000-09 & 8,324 & 168,300 & 2 & 176,626 & 10,700 \\
\hline
\end{tabular}

\section{Scientific Evidence Now Extends the Record into the Past}

The seismologists have of course taken full advantage of historically known dates of earthquakes and tsunamis to help them plot the periodicity with which they occur in different zones. But science has also developed techniques of dating these seismic events at periods long before any historical record, though without, of course, the same exactness about dates or human consequences. The results from Japan have again led the way, notably for the subduction zone of Hokkaido, one of the more dramatic points at which the Pacific plate meets the Japanese island chain. A recent study of sand deposits

11 These first two columns (earthquake and tsunami deaths) are taken from Asian Disaster Reduction Center (Data Book 200o).

12 Micheal Clodfelder (1992, II:1127) gives 33,414 killed in PRRI/Permesta conflict of 19581961, most in 1958. The remainder of the total is a conservative estimate of conflict deaths in the Darul Islam rebellions in Aceh, West Java and Sulawesi.

13 Clodfelder (1992, II:1140) estimated 60,00o East Timorese killed by Indonesian troops in 1975-1984, 2,000 on the TNI side in $1975^{-1976}$ alone, and 2,00o in the East Timor Civil conflict of 1975 . 
in a lagoon and adjacent beach-ridge plain near Kiritappu provided evidence of 15 tsunamis over the past 6000 years, only the last two of which, in 1843 and 1894, are known to history in this frontier for Japanese settlement. Approximate dates were established by carbon-dating of the detritus in the lagoon above and below each deposit layer. By this means it was calculated that the megatsunamis occurred at an average of 400 years interval, though varying unhelpfully from 100 to 800 years. Most chilling was the conclusion, relevant also for Sumatra, that 'most of these tsunamis were larger than any generated at Hokkaido in the last 200 years' (Yuki Sawai et al. 2009).

Although very little comparable work was done on Sumatra before the 2004 disaster, the island has now been declared by a Scripps Institution geodesist to be 'the best area in the world to be able to predict a quake', because of the perceived periodicity of major tears in its subduction zone (Yehuda Bock, as cited in Perkins 2008). The work of Newcomb and McCann (1987:43-44) well before the 2004 tsunami trauma had already established the 1861 earthquake as the most recent rupture of the northern zone of the Sumatra subduction plate, and the 1833 quake as having the same role in the South-Central section. The more abundant research since 2004 appears to have accepted these two events as the most recent critical ones, but sought to push the frontier of knowledge further back in time through physical investigation on the ground.

One method is to examine the layer of sand deposited by a tsunami in the 'swales', or depressions between beach ridges, where cases can be found that are relatively undisturbed by subsequent events. Dating is provided by carbon-dating the organic matter accumulated immediately before and after (i.e. below and above the layer), for an approximate time depth. By these means two international teams of researchers were able to show several layers of sand deposit between the organic accumulated material both at the small tsunami-affected island of Phra Thong, north of Phuket, and on the west coast of Aceh a little north of Meulaboh. At both sites there were older tsunami events, of which the one dated around 780-990 is important for Sumatra's history, as it may have destroyed the camphor port known to travellers of the time as Fansur (thought to be modern Barus). However the most striking correlation between the two sites was for a layer immediately preceding the one which was created by the 2004 tsunami. This was dated to AD 1290-1400 in Aceh and AD 1300-1450 in South Thailand. Allowing for appropriate caution about the dating techniques and the possibilities of erosion and movements in the coastline, this suggests that the most definite tsunami of major scale comparable to 2004 in the Andaman-North Sumatra subduction zone occurred in the fourteenth century (Monecke et al. 2008; Bondevik 2008). 
Another team centred at the California Institute of Technology and the new Earth Observatory Singapore has been analyzing the sudden uplift of coastal reefs in the chain of islands of the subduction zone, by dating the point at which their coral died by sudden elevation out of the water. By methods they call paleogeodesy or 'U-Th disequilibrium dating' of the death of coral, they provide dates much more specific, with a scope for error of only $3^{-18}$ years, than in the case of the carbon- 14 dating of organic matter in the swales mentioned above. On the other hand the more sites they survey, the more complex the record becomes, with no exact correlation of major events between one site and another in the same general section of the subduction zone. Through these means the Caltech team showed in the Mentawai patch off Central Sumatra events they held to correlate with known earthquakes of 1797,1833 and 2007 , though with a surprising degree of certainty that the Mentawai earthquake of 2007 was far from extensive enough to release the pressure built up by subduction since 1797-1833. Further events, on a much larger scale than the Padang earthquake (only 7.6 M), can therefore be expected within the next decade or two (Sieh 2012).

Proceeding further back in time, these researchers have identified events of major uplifts of coral reefs in the Pagai Islands (southern end of the Mentawai chain off Padang) around the years (magnitude of uplift in brackets) 1347 (3.2 m), 1374 (>0.5 m), 1381 (1.3 m), 1607 (1.5 m), $1613(1.2 \mathrm{~m}), 1668$ (>0.5 m) and $1675(0.8 \mathrm{~m}){ }^{14}$ Supported by lesser events around similar dates, these dates support the idea that the west coast of central Sumatra would have suffered major earthquakes accompanied by traumatic tsunamis in the late fourteenth, the early seventeenth century, and the 1797-1833 period known to history, with quieter times in between these three phases.

The same team subsequently worked on Simeulue, the northernmost of the chain of offshore islands, the coral uplift of which reveals events that impact the west coast of Aceh as well as Nias and Simeulue itself. Their findings showed in one Simeulue site major uplifts in about 1394 and 1450 with a minor one about 1430, while another site further south showed major uplift (comparable to the 2005 Nias quake) in 1450 , but little or none at the two earlier dates. ${ }^{15}$ This matches very well the previously discussed evidence of swale sand deposits by the different teams, which identified the period $1290-1450$ as the likeliest time for a major event on the scale of 2004. The Caltech results show that the big tsunami of northern Sumatra and the central Peninsula must have been in the latter half of that period, with probably a series of traumatic events between 1394 and $145^{\circ}$.

14 Sieh (2012). See also Kerry Sieh, Danny Natawidjaja et al. (2008:1674-1677).

15 Meltzner et al. (2010); Meltzner et al. (2009:409). 


\section{Revising Sumatran History}

For the history of Sumatra this puts crucial new evidence on the table. We now know that at least one massive earthquake of around $9 \mathrm{M}$, and an attendant tsunami on the scale of that of 2004, must have accompanied the transition between Buddhist and Islamic Sumatra. This may help explain the seeming lack of continuity between the two eras, and our almost complete ignorance of the history of the earlier one. Almost nothing is understood about the societies which erected the megaliths of many highland locales, or the upland Buddhist temple complexes at (north to south) Padang Lawas, Muara Takus, Pagarruyung, Rambahan, and Karang Berahi. ${ }^{16}$ The camphor-producing Batak area in the north and the gold-producing Minangkabau highlands of the centre when possible exported their products through the nearest ports on the west coast, which should therefore have been the entry points of Indian ideas such as Buddhism. Yet we have surprisingly little evidence of port-cities on the west coast before the Europeans, to rival the east coast river ports of Palembang (older Srivijaya), Muara Jambi, Inderagiri, Siak and Asahan in historic times, or the ceramic-laden site of Kota Cina near Medan in the twelfth-fourteenth centuries.

The only comparable ports on the west coast known to foreign travellers before historic times appear to have been Lamri (somewhere in the northwest corner of Sumatra), shadowy Daha or Barat (Calang), and Fansur (probably at Barus north of Sibolga). Even more mysterious are the clearly Indian placenames that remain on the west coast: Indrapura as a gateway for Kerinci in the extreme south of current West Sumatra province, and a triangle of halfremembered sites in the general area of Banda Aceh - Indrapuri in the interior, Indrapurwa on the coast to the west of the modern city, at a site now wholly submerged, and Indrapatra near the coast above Krung Raya to the east of the city. None of these, however, have left substantial physical remains of an Indian presence. The explanation must lie in part in the extremely volatile nature of the coastal region. Coastal settlements could not become established in the long term because they were disrupted every couple of centuries by severe earthquakes and tsunamis. Even when those port-cities did become established enough to build permanent monuments in stone, the evidence was ultimately obliterated by earthquake and tsunami. Lubuk Tua, the likely centre of the camphor port of Fansur, the most substantial west coast settlement known to Arab, Indian and European traders of the eight to thirteenth centuries, was carefully excavated in the 1990s, but the physical evidence of Indic religion

16 Current understanding of these sites is usefully summarized by John Miksic (2009). 
there remains meager compared with the upland sites mentioned (Guillot 1998-2003). Minangkabau gold was an even older and richer Sumatran export than camphor, giving Sumatra its Sanskrit name Suvarna-dvipa (gold-land). If in the first millennium of the Common Era there was a port for its export somewhere on the west coast of central Sumatra, then the evidence for that has fallen victim to multiple seismic traumas in the interim.

The most substantial state of modern times, the sultanate of Aceh, arose rather quickly in the late fifteenth century and conquered the fertile northern coast to create a strong sultanate in the $15^{20 s}$. Nurudd-din ar-Raniri begins the most reliable of the Aceh chronicles by saying simply that 'Sultan Ali Mughayat Syah [d.1530] was the first to rule the kingdom of Aceh', before which there were no rajas but only village communities (Nuru'd-din ar-Raniri 1966:31). In reality the trading centre of Lamri at the Northwestern tip of Sumatra was known to Arab traders to China from at least the ninth century, and to Marco Polo in 1292, while it sent missions to China in the period 1286-1412. ${ }^{17}$ In the Aceh chronicle tradition, however, Lamri scarcely features as an antecedent. ${ }^{18}$ Aceh appears a new beginning.

The knowledge that the Banda Aceh area is likely to have been hit by at least one major earthquake and tsunami in the period $1340-1450$ helps greatly to explain this discontinuity. Can history help to make the moment more precise? Perhaps only to rule out the period between around 1400 and 1416, when the Ming reportage of the Zheng He visits to Sumatra makes no mention of a devastating tsunami. Ma Huan and other writers of this period make this to be an entirely Muslim place of about a thousand families, no pigs, copper coins, and dwellings 'the same as in the country of [Malayo-Muslim] Samudra.' ${ }^{19}$

This seems a quite different place from the Nan Wu-li described by Wang Dayuan in his 1349 account of travels over the previous two decades. His Lamri was clearly not Muslim or notably urban at all, and its people, naked above the waist, lived 'all over the hills'. ${ }^{20}$ The new post-140o Lamri must have been a settlement of Muslim traders from Samudra-Pasai and elsewhere. The pre-1349 one may have been a coastal outpost of a Buddhist capital further inland, or

17 G.E. Gerini (1909:698-705) provides a chronology of references to Lamri, generously adding some Chinese references to Ta-Shih. See also Tibbets (1979:138-140); Iskandar (1958:24-29).

18 There is a slight qualification to this general neglect. The 'Hikayat Aceh' written in celebration of Sultan Iskandar Muda (r.1607-1636), mentions among his ancestors one Munawar Shah, whose alleged exploits included being a descendent of Alexander the Great, spouse of a heavenly nymph, and 'king of Lamri' (Iskandar 1958:71).

19 Ma Huan (1970:122-124); Schlegel (1901:353-359).

20 Wang Dayuan, as translated in Rockhill (1915:148-149). 
perhaps the remnant of a post-tsunami Lamri which had flourished earlier. A fourteenth century date for a tsunami appears therefore likely, making the Muslim Lamri of the Ming a relatively new entity taking advantage of China's intervention to claim the trading privileges that these missions brought. A post-1416 disaster, on the other hand, would help to explain why even Islamic Lamri was so little remembered in Aceh's origins, ${ }^{21}$ and how a relatively minor injection of a few hundred Cham refugees from the Vietnamese conquest of their capital Vijaya in 1471 could establish such a distinctive imprint on the Acehnese language, which was spread along the northern coast by conquest in the 1520s (Reid 2006:7-8; Thurgood 1999:52, 47-58 passim).

The fragmentary historical record would therefore be compatible with evidence of two distinct mega-tsunamis affecting the Banda Aceh area, perhaps even at the two dates the coral uplift data from Simeulue has unexpectedly presented -1394 and $145^{\circ}$.

\section{The Uncertainty of Java}

In Java, now the most heavily populated part of the Ring of Fire, the record is clearer for volcanic eruptions, both better documented in recent times and more likely to be noticed in the chronicles, than for earthquakes and tsunamis. Java's eighteen historically active strato-volcanos can be relied upon to produce spectacular eruptions every few years. The big eruptions of Explosivity Index (VEI) 4 and above, have occurred regularly in Java, at least at Galunggang (West Java) 1822 and 1982, Merapi (Central Java) 1872 and 2010, Kelut (East Java) 1826, 1919, 1951, 1966, 1990.22 Each causes major local devastation and kills hundreds of people, though their broader effect on climate is harder to document with certainty. Apart from Krakatau (in the strait between West Java and South Sumatra) in 1883, rated VEI 6 for its destructive tsunami and the ash cloud that circled the earth, very little is known about how often the truly giant eruptions have occurred in Java.

As for the remoter past, firm data is scarce and speculation based on Javanese popular tradition tends to take its place. There is a tradition that Sumatra and Java were one island until a vast eruption separated them some 2,00o years ago. And although there is nothing specific to say so in the inscriptions, the disaster

\footnotetext{
21 The sudden disappearance of Lamri from Chinese and other records after 1430 was already noticed by Gerini (1909:682-683).

22 Smithsonian Institute Global Vulcanism Program, 'Large Holocene Eruptions', http:// www.volcano.si.edu/world/largeeruptions.cfm, accessed 7 June 2012.
} 
that overtook the first great Javanese civilization, the one that built Borobudur and Prambanan in the period 600-900 CE, is usually thought to have been a terrible eruption of Gunung Merapi. Certainly parts of the Mataram heartland (present Yogyakarta) were buried by an eruption at some time after the ninth century, including the Sambisari temple $(8 \mathrm{~km}$ northeast of the centre of Modern Yogyakarta) recently discovered to have been buried under 6.5 metres of deposit. As discussed further in this volume by Jan Wisseman Christie, other disasters may have played a role in causing this fertile central Java region to fall silent for six centuries. A bigger eruption from a more distant volcano, less given to regular small eruptions than Merapi, may have caused the crops to fail for a year or more. Moreover a tsunami on the south coast cannot be ruled out as a major disruption of maritime access to Mataram.

An important survey of the historical evidence in 1987 pointed to the danger of the Sumatra subduction zone, but judged that by contrast Java appeared to be aseismic, with few serious earthquake or tsunami events on record (Newcomb and McCann 1987). This view, partly responsible for the inadequate research on Java's past, needs serious revision since the recent run of disasters, which includes two deadly tsunamis on the south coast of Java from deep earthquakes of only magnitude 7.8 (1994) and 7.7 (2006) respectively. For the record before 1900 most of the literature relies on Dutch reportage, although only after 1840, when a Dutch official was placed at the Southwest Java port of Cilacap, was there any Dutch presence at all on the endangered south coast. As we have seen elsewhere, pre-twentieth century Dutch sources seldom recorded natural disasters unless their own infrastructure, personnel or vital interests were affected. Even in the twentieth century the record is poorly documented, and before that significant tsunamis may have occurred without any record.

For earlier episodes Javanese sources must therefore be used, even though they are inadequately dated and generally opaque. They do make clear that the supernatural power of the southern ocean was even more important a theme of palace literature and ritual than that of the Merapi volcano, these being the twin poles, north and south, around which the cosmology of the central Javanese states have revolved. The chronicles of the Mataram kingdom of the seventeenth and eighteenth centuries, and the continuing ritual of its modern successors in Yogyakarta and Surakarta, make clear that both volcano and southern ocean are supernaturally dangerous unless propitiated and harnessed by rightful kings, but it is the Queen of the South Seas (Ratu Kidul) who is the more important figure. She is believed to have given the conquering founders of the Mataram dynasty, the shadowy Senopati (d. 1601) and mighty Sultan Agung (reigned 1613-46) their power to rule by her mystic union with them, though ordinary mortals who provoked her would be carried to a watery grave. 
The most chronologically reliable of the early Javanese chronicles, the Babad ing Sangkala, does provide the most explicit evidence for a tsunami with words translated by Merle Ricklefs (1978:32-33) as 'In Mataram, they moved [the court] to Karta, indeed, when disappearing, all was turned into sea'. The italicized words, repeated three times in slightly different form for emphasis, are a chronogram (a date in words) for the Javanese year 1540, which began in February $1618 \mathrm{CE}$, at the beginning of Sultan Agung's campaigns to conquer Java. There is historic evidence, in other words, to locate a powerful earthquake and tsunami on the south coast of Java, which adds to the urgency of scientific research on the ground (Reid 2012).

Any large tsunami on Java's south coast would also affect Australia's northwest coast, as those of 1994 and 2006 did. Physical research in this sparselypopulated area is unfortunately hardly more advanced than in Indonesia, though one research team has cited geophysical evidence they argue indicates a truly mammoth tsunami in the Kimberleys at some time in the seventeenth century (Bryant et al. 2007).

What all of this suggests, is that in a zone as seismically active as Indonesia we must expect history to be discontinuous, through the effects both of volcanic eruptions alternately enabling and destroying intense agricultural production, and of tsunamis periodically destroying coastal settlements. This helps explain both the remarkably low population of the Indonesian-Philippines island arc as a whole before the nineteenth century, and the dearth of long-term settlements on the coastal plains of western Sumatra and southern Java. ${ }^{23}$ Humans had flourished in this region for longer than in most of Asia, surviving the ice ages as was not possible further north, and enjoying environmental conditions congenial to human life and agriculture. The reason the populations of these archipelagoes remained much sparser than those in other parts of Asia before 1800 must be attributed in part to periodic disasters abruptly reversing the growth of agricultural populations.

23 The low population was previously explained in other terms, see Reid (1987:33-47). 